\title{
Regional Pattern of Heavy Metal Content in Lake Sediments in Northeastern Poland
}

\author{
Wojciech Tylmann • Katarzyna Lysek • \\ Malgorzata Kinder • Janusz Pempkowiak
}

Received: 9 February 2010 / Accepted: 25 June 2010 /Published online: 10 July 2010

(C) The Author(s) 2010. This article is published with open access at Springerlink.com

\begin{abstract}
We investigated sediments from 23 lakes situated in northeastern Poland and analyzed them for major constituents and selected heavy metals. Short sediment cores were collected from the deepest parts of the lakes, and subsequently, a surface layer (0$2 \mathrm{~cm})$ and reference layer $(50-52 \mathrm{~cm})$ were sampled from each. In the collected samples, the content of the major constituents (organic matter, carbonates, and minerogenic material) and chosen heavy metals $(\mathrm{Cd}$, $\mathrm{Cu}, \mathrm{Ni}, \mathrm{Pb}$, and $\mathrm{Zn}$ ) was analyzed. In the reference layer, representing natural metal content, we identified quite a substantial diversity among lakes, making it difficult to pinpoint one geochemical background value for the whole region. A multivariate analysis of the interrelationships among elements and a comparison of the median values revealed no statistically significant differences between surface and reference levels. The ratio of the mean content in the surface and reference sediments ranged from 0.9 to 1.6, indicating the lack of or only slight anthropogenic
\end{abstract}

W. Tylmann $(\bowtie) \cdot$ K. Lysek $\cdot$ M. Kinder

Department of Geomorphology \& Quaternary Geology, Institute of Geography, Gdańsk University,

Dmowskiego 16a,

80264 Gdańsk, Poland

e-mail: geowt@univ.gda.pl

J. Pempkowiak

Department of Marine Chemistry and Biochemistry, Institute of Oceanology, Polish Academy of Sciences, Powstańców Warszawy 55,

81712 Sopot, Poland pollution in surface sediments. From a spatial perspective, higher metal contents were observed in the eastern part of the study area, but this trend manifested in both surface and reference sediments. Thus, the inference is that the recently accumulated sediments are characterized by a content that is representative of the natural geochemical background for the selected metals.

Keywords Lake sediments · Pollution · Heavy metals · Enrichment factor $\cdot$ Northeastern Poland

\section{Introduction}

Anthropogenic pollution of the natural environment has a long history (Brännvall et al. 2001; Renberg et al. 2000; Weiss et al. 1999), but without doubt, the last 200 years have brought the greatest increase, caused mainly by the industrial revolution. One of the effects of environmental pollution is an increase in heavy metal content in lake sediments, which is commonly regarded as a good indicator of human-induced pollution (Nriagu 1996). In the case of lake systems, this increase can result from both a global trend to an increase in atmospheric pollution and from the presence of local pollution sources in lake catchments. An analysis of targets unaffected by local sources enables assessment of the level and regional diversity of the atmospheric deposition of heavy metals. Such lakes are usually situated in remote areas or in regions 
with poorly developed industrial infrastructure and small transformations of the natural environment.

Lake sediments are especially susceptible to heavy metal accumulation and typically have metal concentrations several orders of magnitude higher than those in overlying waters (Stumm and Baccini 1978). However, metals are introduced into lakes not only as a result of pollution but also by processes of rock weathering in the catchments. The pollution level can be estimated by high-resolution analysis of heavy metal contents in non-disturbed sediment cores dated by radioisotopic methods, as has been documented in numerous papers (e.g., Birch et al. 1996; Couillard et al. 2004; Gallon et al. 2005; Gäbler and Suckow 2003; Kobber et al. 1999; Shotbolt et al. 2006; Schottler and Engstrom 2006). This approach is, however, time consuming and expensive; thus, a large group of lakes in a given area cannot be studied. A possible solution is the application of the "topbottom" approach, which relies on comparing surface (recent) sediments with sediments of deeper layers deposited in the pre-industrial period (Smol 2008). This approach is a considerable simplification but has several fundamental advantages, including above all that it is a much faster and cost effective way to study a large group of lakes, involving several dozen or even several hundred targets. The data obtained in such a way can be statistically analyzed, making it possible to obtain a regional distribution of the natural background values of heavy metal content and to estimate the value of anthropogenic enrichment (Dauvalter 1994; Johansson et al. 1995; Rognerud and Fjeld 2001). The top-bottom approach has also been extensively used for evaluating the changes in acidification and eutrophication of lakes (e.g., Dixit et al. 2002; Quinlan and Smol 2002).

Northeastern Poland is one of the Europe's leastpolluted regions because of a lack of both large industrial centers and intensive agriculture. At the onset of the second half of the twentieth century, this area was practically unpolluted; only the last several decades have brought about local industrial development and larger-scale agriculture. This area also has the highest lake density in Poland, where lake systems form one of the most important ecological habitats. The development of both agriculture and mass tourism has caused considerable eutrophication and contamination of surface waters in this region (Marszelewski 2005). However, there is no informa- tion on lakes unaffected by local pollution sources, which may yield signs of regional increases in environmental pollution. In this context, the aim of this study was to estimate the potential enrichment of recent lake sediments with heavy metals as a result of increased atmospheric pollution in the second half of the twentieth century. This endeavor also required determination of the regional diversity of the natural content of the analyzed metals in pre-industrial sediments, constituting the reference level.

\section{Materials and Methods}

\subsection{Study Sites}

Sediment samples were collected during a field trip in 2005 from 23 lakes situated in the Mazurskie and Suwalskie Lakelands (Fig. 1). The lakes were selected on the basis of two main criteria: (1) lack of significant local sources of pollution in the lake surroundings and (2) similar morphometric features, i.e., a small surface area and relatively great depth. Only two of the investigated lakes had surface areas of over 100 ha, maximum depth ranges were from 16.1 to $49.6 \mathrm{~m}$, and mean depth ranged from 5.1 to 17.4. In a vast majority of cases, the bottom topography was not diverse, with the deepest point located in the central part of the lake. Thus, in morphometric terms, the lakes form a compact group with similar features.

On the other hand, the selected lakes represent a wide range of diversity in terms of geological structure, hydrological types, and land use (Table 1). All the investigated lakes are situated in areas of postglacial accumulation consisting of typical formations, such as glacial tills or fluvioglacial sands and gravels. In several cases, there is a significant proportion of clay and silt as well as peat. Flowthrough lakes dominate; there are only five lakes without outflow. In terms of the land use of the immediate catchments, three types are distinguished: forests, agriculture (arable fields, meadows, and pastures), and mixed, where the surroundings of the lake are partially covered by forests and partially used agriculturally. Most of the investigated lakes are situated in agriculturally used areas (11), followed by those in mixed-use areas (seven), and five surrounded by forest. 


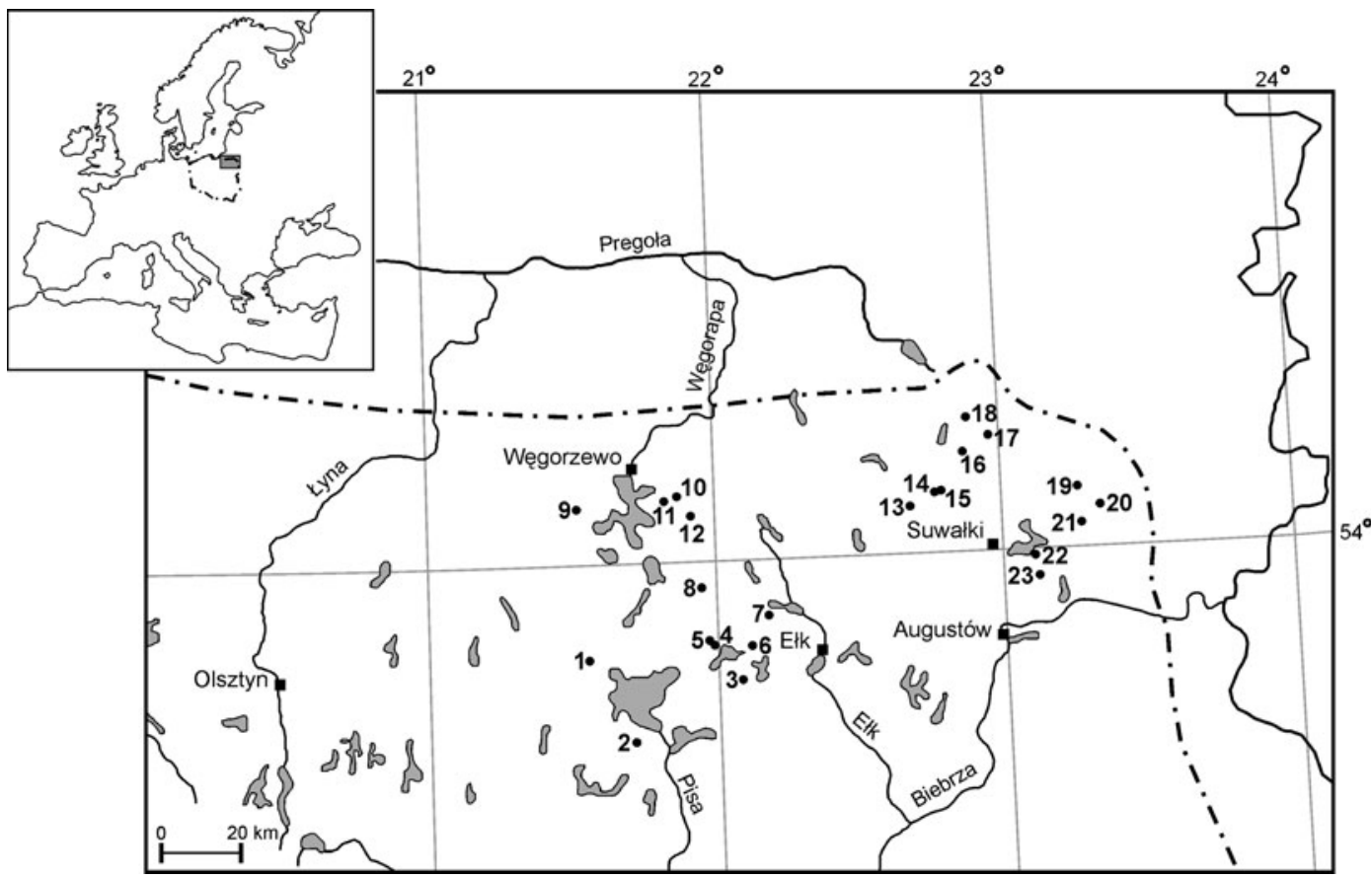

Fig. 1 Location of the study sites (lake details in Table 1)

\subsection{Field Work}

The sediment cores were collected in the deepest parts of the lakes using a gravity corer with a Plexiglas core tube $100 \mathrm{~cm}$ in length with a 96-mm inner diameter (Tylmann 2007). All the cores underwent visual inspection, and only those with an apparently undisturbed sediment-water interface were selected for analyses. After being collected, the cores were kept in vertical position and immediately subsampled in the field to prevent disturbance of flocculent surface sediments. The cores were extruded vertically, and samples were collected from the tray placed on top of the tube. This technique has been applied in numerous investigations and provides no disturbance even in the least consolidated sediments (Glew et al. 2001; Tylmann 2007). The collected samples were placed in tightly sealed plastic containers and stored at a temperature of $4^{\circ} \mathrm{C}$ prior to analyses.

To document changes in metal content, the uppermost $2 \mathrm{~cm}$ of sediment core were collected based on the assumption that they represent up to the last dozen years of accumulation, followed by collection of the sediment from a depth of $50-52 \mathrm{~cm}$, which was treated as a reference level. Studies on sedimentation rate of lake sediments in northeastern Poland (Żurek 1986) showed that the mean rate during the Holocene was ca. $1 \mathrm{~mm}$ year $^{-1}$. In light of the available data concerning recent sedimentation rate in the lakes of northern Poland (Goslar et al. 1999; Tylmann 2004, 2005), this sedimentation ranges from less than one to several $\mathrm{mm}$ year $^{-1}$; generally, however, on average it is $2-3 \mathrm{~mm}$ year ${ }^{-1}$. Moreover, ${ }^{210} \mathrm{~Pb}$ dating and varve chronology were done for one of the lakes analyzed in this study (Lake Lazduny). It clearly showed that the sediments from a depth of $30 \mathrm{~cm}$ were older than 150 years (Tylmann et al. 2007). Relying on the above-mentioned facts, the sediment from the assumed reference level must be at least over 100 years old. Thus, it dates back to the period before the occurrence of pollution in this area and should represent the content of the analyzed metals at the natural level or close to it.

\subsection{Laboratory Analyses}

Firstly, the sediment samples were sieved with a 0.2$\mathrm{mm}$ sieve, and only a finer fraction was selected for further research. The determinations of metal content in such a fraction are used in Poland in geochemical classification of water sediment purity (Bojakowska and Sokołowska 1998). Next, the sediment was dried at $105^{\circ} \mathrm{C}$ and homogenized in an agate mortar. 
Table 1 Basic features of the study lakes

\begin{tabular}{|c|c|c|c|c|c|c|c|c|c|c|c|}
\hline $\begin{array}{l}\text { Map } \\
\text { site no }\end{array}$ & Lake name & $\begin{array}{l}\text { Latitude } \\
{[\mathrm{N}]}\end{array}$ & $\begin{array}{l}\text { Longitude } \\
{[\mathrm{E}]}\end{array}$ & $\begin{array}{l}\text { Altitude } \\
\text { [m a.s.1.] }\end{array}$ & $\begin{array}{l}\text { Surface } \\
\text { area }[\mathrm{ha}]\end{array}$ & $\begin{array}{l}\text { Max. } \\
\text { depth } \\
{[\mathrm{m}]}\end{array}$ & $\begin{array}{l}\text { Mean } \\
\text { depth } \\
{[\mathrm{m}]}\end{array}$ & Inflow & Outflow & $\begin{array}{l}\text { Surface } \\
\text { geology }\end{array}$ & Land use \\
\hline 1 & Głębokie & $53^{\circ} 48.7^{\prime}$ & $21^{\circ} 30.5^{\prime}$ & 122.4 & 47.3 & 34.3 & 11.8 & + & + & $\mathrm{t}$ & Agriculture \\
\hline 2 & Jegocin & $53^{\circ} 40.1^{\prime}$ & $21^{\circ} 41.5^{\prime}$ & 122.0 & 127.4 & 36.1 & 9.0 & - & - & fg & Forest \\
\hline 3 & Przykop & $53^{\circ} 47.8^{\prime}$ & $22^{\circ} 05.6^{\prime}$ & 121.0 & 12.5 & 17.0 & 5.1 & - & - & fg & Forest \\
\hline 4 & Rzęśniki & $53^{\circ} 51.6^{\prime}$ & $21^{\circ} 57.2^{\prime}$ & 125.3 & 14.2 & 26.0 & 7.8 & + & + & $\mathrm{t}, \mathrm{p}$ & Forest \\
\hline 5 & Lazduny & $53^{\circ} 51.4^{\prime}$ & $21^{\circ} 57.2^{\prime}$ & 128.8 & 10.6 & 22.4 & 9.1 & - & - & $\mathrm{t}, \mathrm{p}$ & Forest \\
\hline 6 & Mleczówka & $53^{\circ} 51.5^{\prime}$ & $22^{\circ} 07.4^{\prime}$ & 122.6 & 69.0 & 18.8 & 5.2 & + & + & $\mathrm{p}, \mathrm{c}, \mathrm{fg}$ & Mixed \\
\hline 7 & Garbaś & $53^{\circ} 54.3^{\prime}$ & $22^{\circ} 09.9^{\prime}$ & 129.8 & 42.5 & 38.0 & 10.2 & + & + & $\mathrm{p}, \mathrm{fg}$ & Mixed \\
\hline 8 & Żywy & $53^{\circ} 04.2^{\prime}$ & $22^{\circ} 03.1^{\prime}$ & 131.0 & 118.8 & 24.5 & 6.0 & + & + & $\mathrm{fg}, \mathrm{p}$ & Mixed \\
\hline 9 & Siniec Mały & $54^{\circ} 09.1^{\prime}$ & $21^{\circ} 30.9^{\prime}$ & 130.4 & 11.1 & 19.0 & 5.1 & - & - & fg & Forest \\
\hline 10 & Lemięt & $54^{\circ} 09.5^{\prime}$ & $21^{\circ} 48.8^{\prime}$ & 116.8 & 78.8 & 18.3 & 5.9 & + & + & $\mathrm{c}, \mathrm{fg}$ & Mixed \\
\hline 11 & $\begin{array}{l}\text { Głęboka } \\
\text { Kuta }\end{array}$ & $54^{\circ} 10.1^{\prime}$ & $21^{\circ} 55.1^{\prime}$ & 134.0 & 16.5 & 22.0 & 6.6 & + & + & fg & Agriculture \\
\hline 12 & Żabińskie & $54^{\circ} 08.0^{\prime}$ & $21^{\circ} 55.4^{\prime}$ & 116.8 & 40.1 & 42.5 & 9.1 & + & + & $\mathrm{t}, \mathrm{c}, \mathrm{fg}, \mathrm{p}$ & Mixed \\
\hline 13 & Skazdubek & $54^{\circ} 06.9^{\prime}$ & $22^{\circ} 41.6^{\prime}$ & 166.2 & 22.8 & 22.3 & 5.5 & - & + & $\mathrm{t}, \mathrm{p}$ & Agriculture \\
\hline 14 & Grabienisz & $54^{\circ} 08.8^{\prime}$ & $22^{\circ} 46.5^{\prime}$ & 194.2 & 11.6 & 21.4 & 8.8 & + & + & $\mathrm{t}$ & Agriculture \\
\hline 15 & Ożewo & $54^{\circ} 08.8^{\prime}$ & $22^{\circ} 48.8^{\prime}$ & 191.3 & 53.6 & 49.6 & 17.4 & + & + & $\mathrm{c}, \mathrm{t}$ & Agriculture \\
\hline 16 & Szurpiły & $54^{\circ} 13.8^{\prime}$ & $22^{\circ} 53.5^{\prime}$ & 183.1 & 80.9 & 46.2 & 10.0 & + & + & $\mathrm{c}, \mathrm{fg}, \mathrm{p}$ & Agriculture \\
\hline 17 & Jałowo & $54^{\circ} 16.1^{\prime}$ & $22^{\circ} 57.3^{\prime}$ & 193.6 & 20.1 & 16.1 & 6.8 & + & + & $\mathrm{t}, \mathrm{p}$ & Agriculture \\
\hline 18 & Kolje & $54^{\circ} 16.8^{\prime}$ & $22^{\circ} 53.3^{\prime}$ & 149.2 & 16.1 & 27.5 & 10.9 & + & + & $c, f g$ & Mixed \\
\hline 19 & Klejwy & $54^{\circ} 09.4^{\prime}$ & $23^{\circ} 16.8^{\prime}$ & 137.8 & 12.0 & 30.2 & 9.2 & + & + & $\mathrm{t}$ & Agriculture \\
\hline 20 & Sztabinki & $54^{\circ} 07.7^{\prime}$ & $23^{\circ} 25.1^{\prime}$ & 134.6 & 60.5 & 27.8 & 5.6 & + & + & fg & Agriculture \\
\hline 21 & Dmitrowo & $54^{\circ} 05.3^{\prime}$ & $23^{\circ} 16.9^{\prime}$ & 135.5 & 61.2 & 42.0 & 10.6 & + & + & $\mathrm{t}, \mathrm{c}$ & Agriculture \\
\hline 22 & Mulaczysko & $54^{\circ} 00.6^{\prime}$ & $23^{\circ} 06.0^{\prime}$ & 134.0 & 18.3 & 20.5 & 5.7 & - & - & $\mathrm{t}, \mathrm{fg}$ & Agriculture \\
\hline 23 & Blizienko & $53^{\circ} 57.3^{\prime}$ & $23^{\circ} 06.8^{\prime}$ & 133.3 & 38.8 & 16.8 & 6.3 & + & + & $\mathrm{fg}, \mathrm{c}, \mathrm{p}$ & Mixed \\
\hline
\end{tabular}

$F g$ fluvioglacial sediments, $t$ glacial till, $c$ clay and silt, $p$ peat

The weight loss on ignition (LOI) was used to determine the main components of the sediment according to the procedure described by Heiri et al. (2001). The organic matter and carbonate contents were determined by burning samples at $550^{\circ} \mathrm{C}$ for $4 \mathrm{~h}$, followed by combustion at $925^{\circ} \mathrm{C}$ for $2 \mathrm{~h}$, respectively. From the remaining part of the sediment, biogenic silica was removed by heating in $2 \mathrm{M} \mathrm{Na}_{2} \mathrm{CO}_{3}$ $\left(4 \mathrm{~h}, 90^{\circ} \mathrm{C}\right)$ following the procedure proposed by Eggimann et al. (1980). The final residue after filtering and drying was identified as minerogenic material constituting only the allochthonous element (Håkanson and Jansson 2002).

Dried sediment samples $(0.5 \mathrm{~g})$ were transferred to Teflon(R) vessels, and the wet digestion was performed using a mixture of $\mathrm{HF}$ and $\mathrm{HClO}_{4}$. The concentrations of metals $(\mathrm{Cd}, \mathrm{Cu}, \mathrm{Ni}, \mathrm{Pb}$, and $\mathrm{Zn})$ were determined using the AAS method with a Thermo Jarrell Ash spectrometer Video 11E. The procedure has been used previously for the analysis of marine (Pempkowiak 1991) and lake sediments (Andersen and Pempkowiak 1999). Quality control was achieved by analysis of confirmed reference material ABSS-1 obtained from the Baltic Sea Research Institute, Warnemuende, Germany. Test with standard reference sediments showed that the recovery ranged from $85 \%$ to $100 \%$ (Table 2). Measurement precision based on repeatedly analyzed samples and expressed as relative standard deviation from the mean value ranged from $0.8 \%$ to $3.5 \%$ for the analyzed metals.

\subsection{Data Processing}

The results of chemical determinations are presented as the median, minimum, and maximum values for the whole group of lakes with a division into the 
Table 2 Comparison of the certified and obtained values for the reference sediment ABSS-1

\begin{tabular}{|c|c|c|c|}
\hline Element & $\begin{array}{l}\text { Reference mean } \\
\text { value }\end{array}$ & $\begin{array}{l}\text { Measured } \\
\text { value }\end{array}$ & $\begin{array}{l}\text { Percentage } \\
\text { recovery }\end{array}$ \\
\hline $\mathrm{Cd}$ & 1.0 & 0.9 & 85.9 \\
\hline $\mathrm{Cu}$ & 50.0 & 48.6 & 97.2 \\
\hline $\mathrm{Ni}$ & 36.0 & 36.1 & 100.3 \\
\hline $\mathrm{Zn}$ & 304.0 & 306.1 & 100.7 \\
\hline $\mathrm{Pb}$ & 94.0 & 80.5 & 85.7 \\
\hline
\end{tabular}

surface and reference levels. The increase in heavy metal content in surface sediments is presented as the enrichment factor $(\mathrm{EF})$, being a ratio of metal content in surface sediments to the value of the natural geochemical background.

$\mathrm{EF}=C_{\mathrm{S}} / C_{\mathrm{R}}$

where $C_{\mathrm{S}}$ is the concentration of the analyzed element in a surface sample; $C_{\mathrm{R}}$ is the concentration of the analyzed element in reference sediments.

The background value was determined based on the content of particular metals in reference sediments as a median plus one or two standard deviations, depending on the distribution of values in the whole group. To test for differences between concentrations in surface and reference sediments, the Student's $t$ test was used for matched pairs.

To characterize the interrelationships among the major sediment constituents and heavy metals, the data set was also subjected to multivariate analysis. Two data matrices (surface and reference levels), with 23 samples, each characterized by eight properties (organic matter, carbonates, minerogenic matter, $\mathrm{Cd}$, $\mathrm{Cu}, \mathrm{Ni}, \mathrm{Pb}$, and $\mathrm{Zn}$ ), were subjected to analysis. The CANOCO 4.5 for Windows package was used for statistical assessment (Lepš and Šmilauer 2003). A principal component analysis (PCA) was carried out on previously standardized variables.

\section{Results}

\subsection{Sediment Characteristics}

The sediments were collected from the deepest sites of the lakes where fine-grained sediments of various content of organic matter, carbonates, and minerogenic material are deposited. During the preliminary sieving of the material on a $0.2-\mathrm{mm}$ sieve, it was observed that only in some cases did the sediments contain elements of a coarser fraction, usually undecomposed organic remains. Sandy material was not observed; the sediment was composed of fine silty and clayey fractions.

Organic matter content determined on the basis of LOI ranged widely both in the surface and reference levels (Fig. 2). The values of the median and standard deviation for the surface were $32.3 \pm 11.2 \%$, while for the reference level, they were $20.2 \pm 16.1 \%$. The difference was statistically significant ( $t$ test for matched pairs, $p<0.05$ ). Thus, it can be concluded that the organic matter content in surface sediments was on average higher than in reference sediments.

In the case of carbonates and minerogenic material content, the differences among lakes were also large (Fig. 2); however, there were no statistically significant differences between surface and reference sediments for the whole group. The median values for carbonates were $11.1 \pm 10.8 \%$ in the case of surface sediments and $6.9 \pm 15.0 \%$ in the reference level. The analogous values of minerogenic material were $36.5 \pm 18.7 \%$ (surface) and $42.8 \pm 23.2 \%$ (reference). Thus, minerogenic material coming from the catchments is the most important component of the sediments. These results underline the importance of erosion and sediment transport in the catchments, as the main source of sediments for most of the analyzed lakes. The second source of sedimentary material is primary production in lakes, and carbonates seem to be of minor importance.

\subsection{Heavy Metal Concentrations}

Within the scope of the analyzed heavy metals, considerable differences between lakes were observed (Fig. 2); however, it should be noted that the obtained concentrations were generally low or very low for both surface sediments and the reference level. Statistically significant differences between the levels were found only in Cd content, based on the $t$ test (Table 3). Yet, the calculated enrichment factor of 1.6 could be seen as rather insignificant. A similar value (1.5) was obtained for $\mathrm{Ni}$; however, because of a wide range of results among particular lakes, the difference in the mean content in surface and reference sediments could not be regarded as statistically significant. In the cases of $\mathrm{Cu}, \mathrm{Pb}$, and $\mathrm{Zn}$, there also were no statistically significant differences between the 
Fig. 2 The element concentrations (median, minimum, and maximum) in surface and reference sediments (values of $\mathrm{LOI}, \mathrm{CaCO} 3$, and $\mathrm{MM}$ are given in \%)
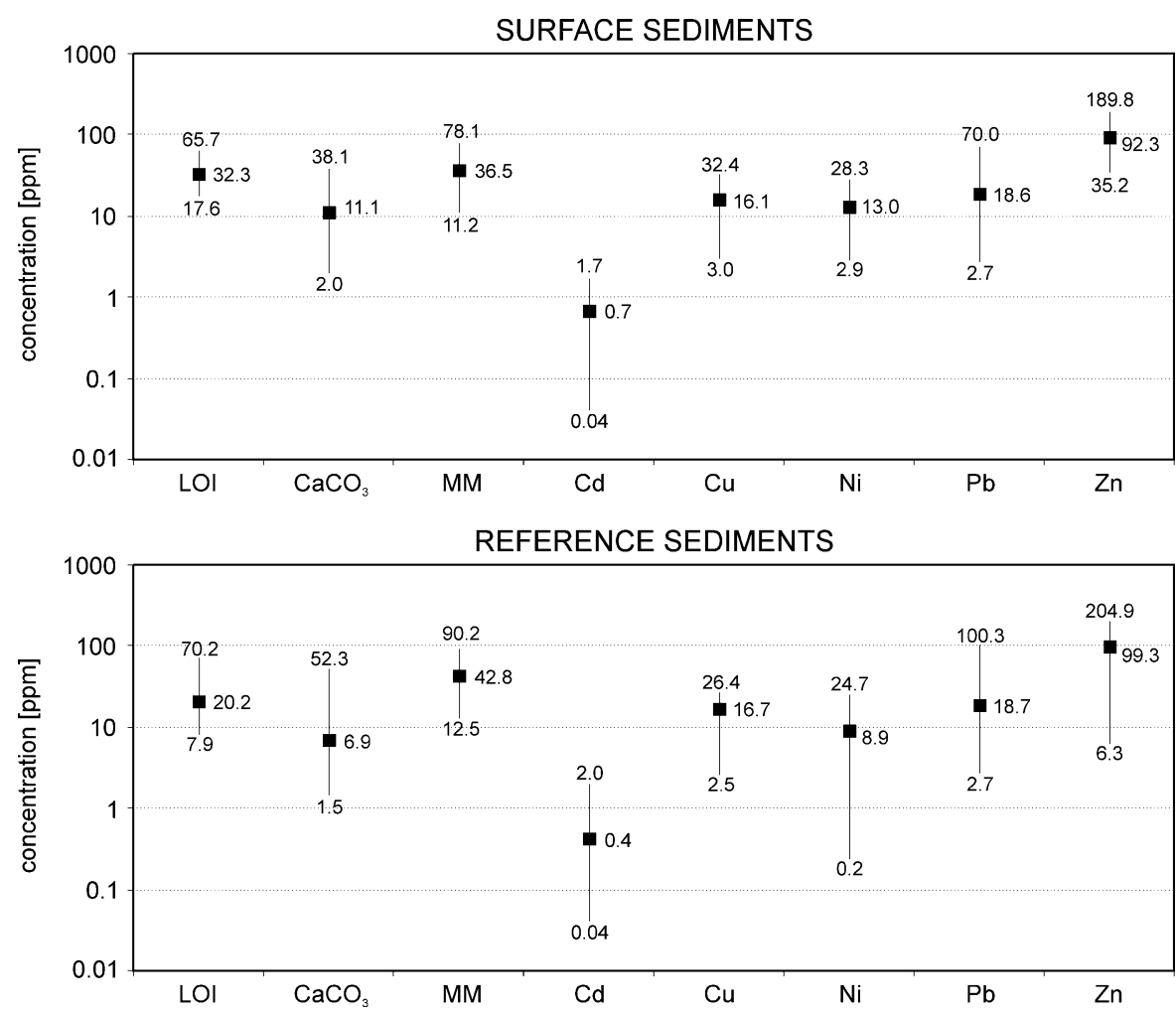

surface and reference sediments. Moreover, the values of the median were higher in the reference sediments, which further stress the apparent lack of anthropogenic enrichment in recent sediments.

\subsection{Spatial Distributions}

Figure 3 presents the spatial variability of the analyzed metals in the surface and reference sediments. On this basis, we conclude that the concentrations of metals in sediments of the analyzed lakes increase toward the northeast. This conclusion is confirmed by the median values for both groups, but this increase concerns both surface and reference sediments (Table 4). Thus, once

Table 3 Median concentrations ( $\mathrm{ppm}$ ) in surface and reference sediments, enrichment factor (EF), and $t$ test values

\begin{tabular}{lrrrr}
\hline Element & Surface & Reference & EF & $t$ test \\
\hline $\mathrm{Cd}$ & 0.7 & 0.4 & 1.6 & 2.36 \\
$\mathrm{Cu}$ & 16.1 & 16.7 & 1.0 & 0.11 \\
$\mathrm{Ni}$ & 13.0 & 8.9 & 1.5 & 0.80 \\
$\mathrm{~Pb}$ & 18.6 & 18.7 & 1.0 & 0.35 \\
$\mathrm{Zn}$ & 92.3 & 99.3 & 0.9 & 0.68 \\
\hline
\end{tabular}

again, it cannot have resulted from increased pollution but from differences in the natural content of the analyzed metals in the group of lakes situated in the Suwalskie Lakeland. Moreover, because of the wide range of the obtained values within the groups (SD values), this difference cannot be regarded as statistically significant, either at the surface or reference level.

\subsection{Statistical Relationships}

The data obtained from the sediments in the surface and reference levels were subjected to a multivariate analysis using PCA. In the case of both data sets, the first four principal components explained in total over $90 \%$ of the whole variance (Table 5); however, most important were the first two components (PC1 and PC2), which accounted for $84.8 \%$ and $74.6 \%$ of variance respectively in surface and reference sediments. Biplots presenting interrelationships of the analyzed elements and lakes (Fig. 4) indicated a definite similarity between surface and reference sediments. The analyzed elements had an almost identical character with small shifts of $\mathrm{Cu}$ and $\mathrm{Ni}$. The latter in surface sediments was strongly related to minerogenic material, but in reference sediments, this 
SURFACE SEDIMENTS
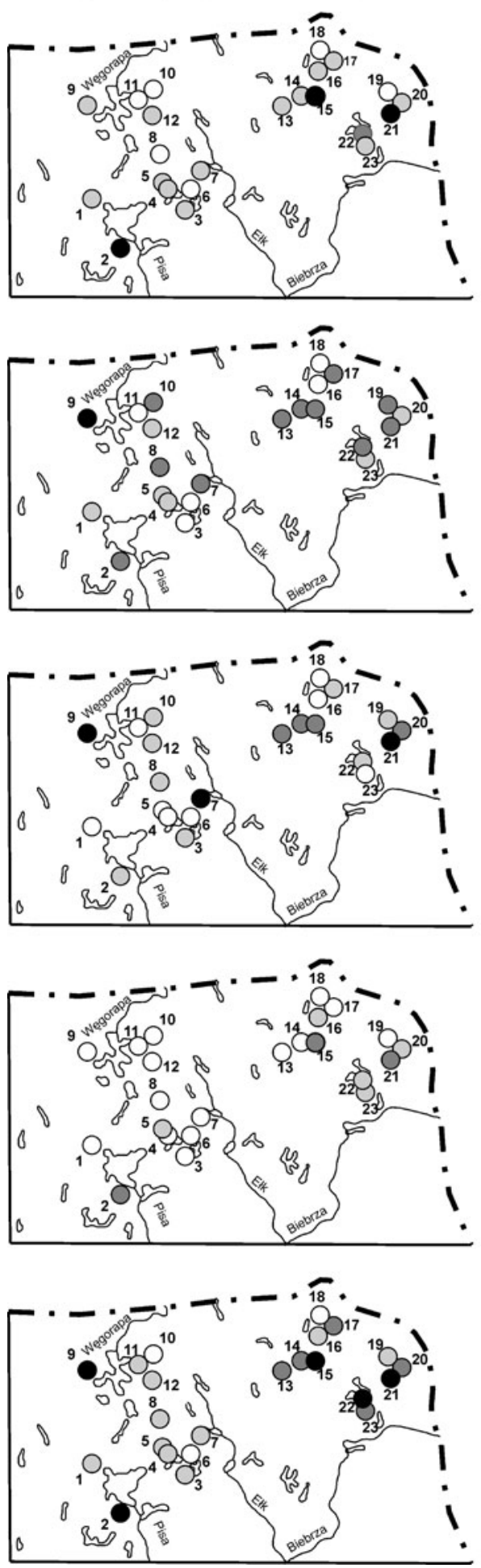

REFERENCE SEDIMENTS
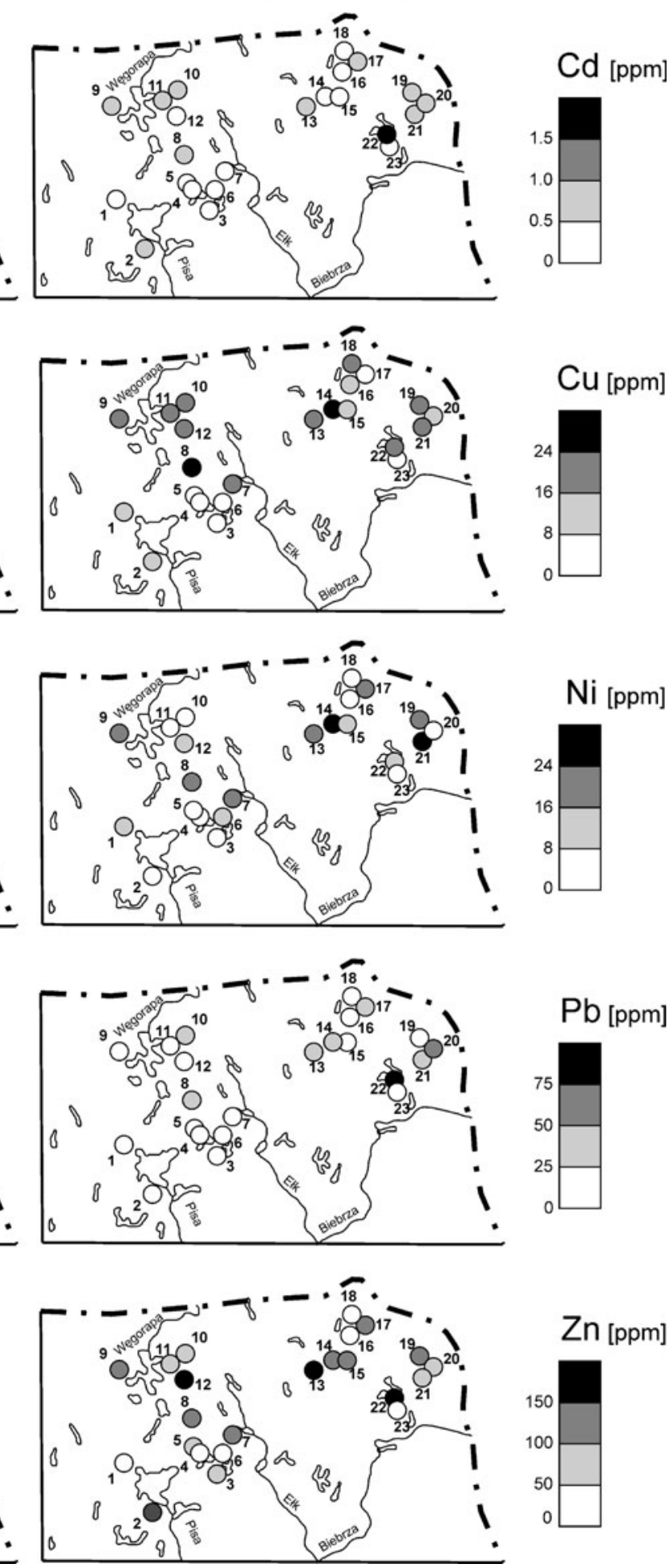

Fig. 3 Spatial distribution of heavy metal content in lake sediments in northeastern Poland 
Table 4 Median concentrations (ppm) and standard deviations (SD) for Mazurskie and Suwalskie Lakelands

\begin{tabular}{lccccc}
\hline \multirow{2}{*}{ Element } & \multicolumn{2}{l}{ Masurian Lakeland } & & \multicolumn{2}{l}{ Suwałki Lakeland } \\
\cline { 2 - 3 } \cline { 5 - 6 } \cline { 5 - 6 } & Surface & Reference & & Surface & Reference \\
\hline $\mathrm{Cd}$ & $0.6 \pm 0.4$ & $0.4 \pm 0.3$ & & $0.8 \pm 0.4$ & $0.5 \pm 0.6$ \\
$\mathrm{Cu}$ & $12.8 \pm 7.9$ & $14.5 \pm 8.6$ & & $16.9 \pm 6.5$ & $16.7 \pm 7.3$ \\
$\mathrm{Ni}$ & $9.1 \pm 8.3$ & $8.3 \pm 6.6$ & & $13.7 \pm 7.4$ & $15.4 \pm 9.1$ \\
$\mathrm{~Pb}$ & $15.6 \pm 15.1$ & $10.6 \pm 9.3$ & & $28.9 \pm 19.4$ & $27.6 \pm 28.6$ \\
$\mathrm{Zn}$ & $75.5 \pm 39.3$ & $97.1 \pm 48.9$ & & $124.7 \pm 46.7$ & $112.2 \pm 60.7$ \\
\hline
\end{tabular}

relationship was weaker. There was a clear relationship of $\mathrm{Cd}$ and $\mathrm{Pb}$ with associations with LOI in both levels and a completely opposite relationship of $\mathrm{CaCO}_{3}$ with all the analyzed metals. Comparison of the information about present land use in catchments (Table 1) and multivariate analysis results shows that there is no clear relationship between metal content and present land use in the catchments. Furthermore, there is no significant difference between flowthrough lakes and closed basins.

\section{Discussion}

4.1 Natural Variability of Trace Metals in the Preindustrial Period

Because the group of lakes covered by the research was quite large, the results obtained on the reference level can be used to estimate the range of the natural variability of the analyzed metals in lake sediments of northeastern Poland. The level of the natural concentration of metals in lake sediment depends mainly on the geological structure of the catchment and intensity of material transport from the catchment into the lake as well as on the properties of the sediment itself, e.g., granulometric composition and organic matter content (Engstrom and Wright 1984; Boyle 2001). Estimating

Table 5 Percent variance explained by the first four principal components (PC1-PC4)

\begin{tabular}{llllll}
\hline & PC1 & PC2 & PC3 & PC4 & Total \\
\hline Surface level & 62.64 & 22.18 & 8.08 & 3.26 & 96.16 \\
Reference level & 54.19 & 20.38 & 9.36 & 7.39 & 91.32 \\
\hline
\end{tabular}
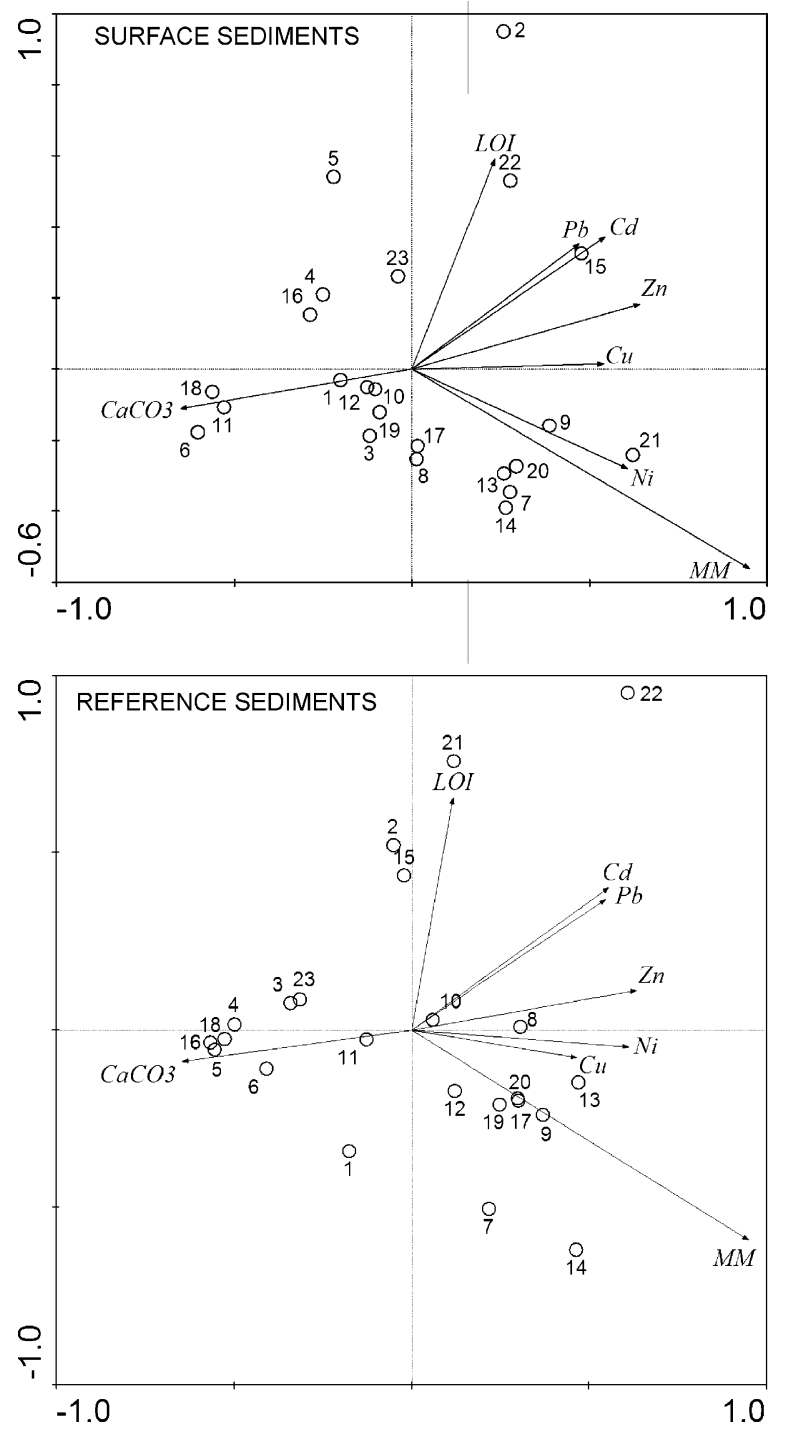

Fig. 4 Biplots from a PCA of the investigated elements

natural fluctuations of metal content in lake sediments of a given region is very important because they constitute a reference value when determining the degree of sediment pollution. If data concerning local or regional natural values are unavailable, usually data concerning the mean content of elements in the Earth's crust are used. These values can deviate from the actual natural content, which in turn can lead to an erroneous estimation of the pollution value.

A comparison of data concerning the mean metal content in the Earth's crust (Turekian and Wedepohl 1961) with values of the geochemical background assumed for lake and river sediments of this area of Poland (Bojakowska and Sokołowska 1998) indicates 
Table 6 Natural background concentrations (ppm) according to selected sources

\begin{tabular}{llll}
\hline Element & $\begin{array}{l}\text { Turekian and } \\
\text { Wedepohl (1961) }\end{array}$ & $\begin{array}{l}\text { Bojakowska and } \\
\text { Sokołowska (1998) }\end{array}$ & $\begin{array}{c}\text { This study (median values for } \\
\text { reference level sediments) }\end{array}$ \\
\hline $\mathrm{Cd}$ & $<0.3$ & $<0.5$ & $<0.4$ \\
$\mathrm{Cu}$ & $<45$ & $<6$ & $<17$ \\
$\mathrm{Ni}$ & $<68$ & $<5$ & $<9$ \\
$\mathrm{~Pb}$ & $<20$ & $<10$ & $<19$ \\
$\mathrm{Zn}$ & $<95$ & $<48$ & $<99$ \\
\hline
\end{tabular}

significant differences in mean contents for all metals analyzed in this study (Table 6). Except for Cd, considerably lower natural values are recorded in Poland. This finding was also confirmed by the results obtained here, except for $\mathrm{Pb}$ and $\mathrm{Zn}$, which had median values for the reference level that were comparable to the data of Turekian and Wedepohl (1961) and much higher than those identified by Bojakowska and Sokołowska (1998).

A comparison of the mean values does not offer complete information and can be misleading: the variability of natural metal content in sediments of different lakes of the same region can be high, as indicated by these sediments from lakes of northeastern Poland (Fig. 5). Only $\mathrm{Cd}$ and $\mathrm{Pb}$ exhibited a small range of results, with the vast majority of them falling into two classes, and $>90 \%$ of all results fell within the range of values lower than the median plus one standard deviation. Unfortunately, for the remaining metals, frequency distributions revealed a large diversity of results, and only slightly above a half of them fell within the range of $\mathrm{Me}+1 \mathrm{SD}$. The spatial variability is not related to annual sums of rainfall in the region, which vary in the range $550-650 \mathrm{~mm} \mathrm{a}^{-1}$ and show opposite spatial pattern, i.e., less precipitation towards the east (Lorenc 2005). Therefore, the local background values are most likely dependent on mineralogical composition of catchment sediments.

This outcome demonstrates the important role of strictly local conditions in the shaping of the natural content of these metals and makes it difficult to calculate the exact values of the geochemical background, which could be accepted as representative of the whole region.

\subsection{Recent Pollution Estimation}

The increase in atmospheric pollution in the twentieth century is detectable in sediments of water bodies even in areas remote from pollution sources (Kashulin
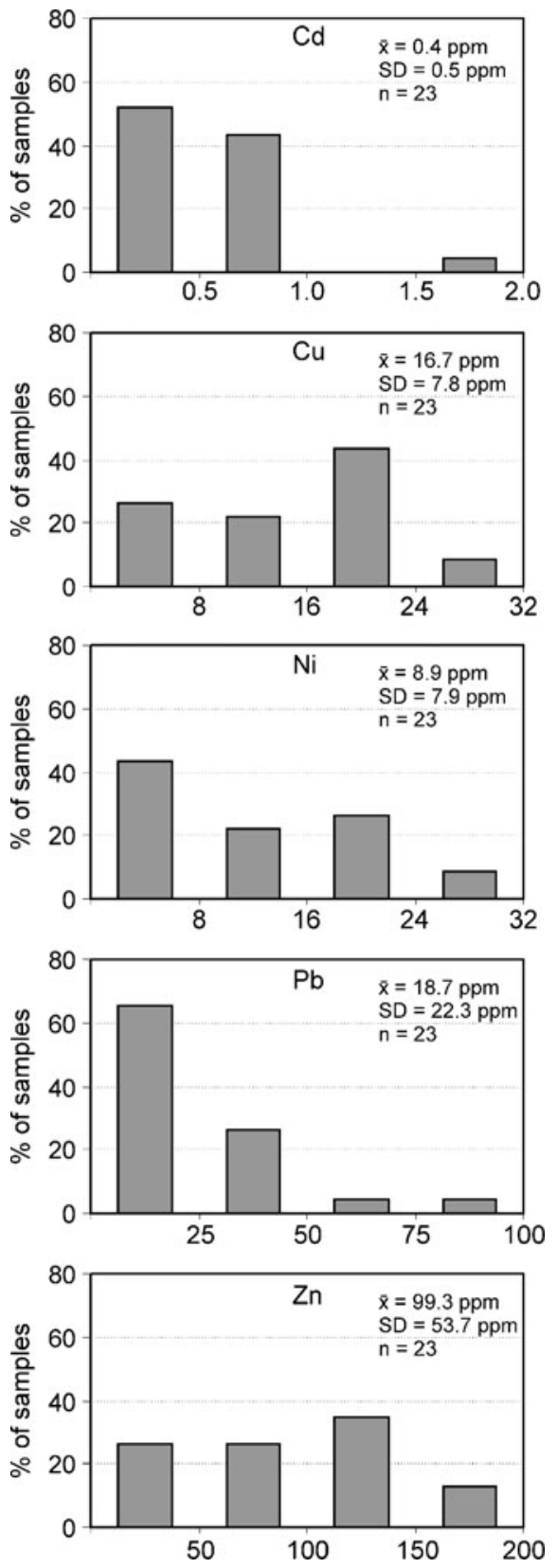

Fig. 5 Frequency distributions of the heavy metal content in reference sediments of the investigated lakes 
et al. 2001; Lucotte et al. 1995; Rognerud and Fjeld 2001). The strongest impact on the spreading of heavy metals in the environment is exerted by mining and metallurgic industries emitting substantial quantities of metals into the atmosphere. Metal concentrations in lake sediments often reflect precisely the value and spatial distribution of sources of pollution emission (e.g., Dauvalter 1994; Moiseenko et al. 1995).

On the other hand, in the case of a lack of significant emission sources in a region, elevated levels of metals in lake sediments are often not observed. The available instrumental data suggest that the area of northeastern Poland has not been affected by regional-scale air pollution (Olendrzyński et al. 2007). In papers discussing pollution signals in lake sediments in this area, sometimes a considerable increase in metal content is reported to have been observed in recent sediments, but these findings concern lakes under the influence of local pollution sources (e.g., Aleksander-Kwaterczak and Prosowicz 2007). In this case, the sedimentary record provides strictly local information.

To obtain information about regional pollution, the targets of the current study were selected so that they were not within the scope of impact of local pollution sources. A comparison of concentrations in reference and surface sediments demonstrated here that there is no statistically significant enrichment attributable to an increase in environmental pollution. It is consistent with results from an area of Lithuania situated a little farther to the east, where no significant increase in heavy metal content in lake sediments was found (Klavinš et al. 1995). Moreover, the research on 48 lakes of the Kashubian Lakeland situated in central northern Poland showed similarly low mean metal contents (Bojakowska and Sokołowska 1996). This supports our conclusion that there is no detectable signal of regional-scale pollution recorded in lake sediments in the study area.

\section{Conclusion}

On the basis of investigations of sediments from 23 lakes of northeastern Poland, varying contents of organic matter and carbonates as well as selected heavy metals were observed. The calculated mean values for the reference and surface levels can be regarded as low in comparison with the current norms of sediment quality in Poland (Bojakowska and Sokołowska 1998). High variability of concentrations in the reference level made it difficult to determine geochemical background values for the whole region. Comparison of concentrations at the reference and surface levels as well, as a multivariate analysis, showed a lack of significant differences between these levels. These findings lead to the conclusion that in the recently accumulated sediments of the investigated lakes of northeastern Poland, the heavy metal content does not diverge from natural background. Thus, the region seems to be promising for investigation of the range of natural changes in sediment geochemistry, and the lakes not affected by recent pollution would be used as reference sites in the frame of existing or planned monitoring systems.

Acknowledgments This work was supported by funding from the NORPOLAR Project (DFG/46/2007). We wish to thank Karolina Czarnecka, Marta Jaźwiecka, and Piotr Woźniak for their help with field work. Two anonymous reviewers are acknowledged for their helpful comments which substantially improved the manuscript.

Open Access This article is distributed under the terms of the Creative Commons Attribution Noncommercial License which permits any noncommercial use, distribution, and reproduction in any medium, provided the original author(s) and source are credited.

\section{References}

Aleksander-Kwaterczak, U., \& Prosowicz, D. (2007). Distribution of $\mathrm{Cd}$, and $\mathrm{Pb}$ in the lake sediments cores from the Hańczańska Bay (Wigry Lake, NE Poland). Limnological Review, 7(4), 219-223.

Andersen, D. O., \& Pempkowiak, J. (1999). Sediment content of metals before and after lake water liming. The Science of the Total Environment, 243(244), 107-118.

Birch, L., Hanselmann, K. W., \& Bachofen, R. (1996). Heavy metal conservation in Lake Cadagno sediments: Historical records of anthropogenic emissions in a meromictic alpine lake. Water Resources, 30(3), 679-687.

Bojakowska, I., \& Sokołowska, G. (1996). Heavy metals in the bottom sediments of lakes in the Kashubian Lakeland (In Polish: Metale ciężkie w osadach jezior Pojezierza Kaszubskiego). Przegląd Geologiczny, 44, 920-923.

Bojakowska, I., \& Sokołowska, G. (1998). Geochemical quality classes of bottom sediments (In Polish: Geochemiczne klasy czystości osadów wodnych). Przeglad Geologiczny, 46(1), 49-54. 
Boyle, J. F. (2001). Inorganic geochemical methods in paleolimnology. In W. M. Last \& J. P. Smol (Eds.), Tracking environmental change using lake sediments. Volume 2-Physical and geochemical methods (pp. 83141). Dordrecht: Kluwer.

Brännvall, M. L., Bindler, R., Emteryd, O., \& Renberg, I. (2001). Four thousand years of atmospheric lead pollution in northern Europe: A summary from Swedish lake sediments. Journal of Paleolimnology, 25, 421-435.

Couillard, Y., Courcelles, M., Cattaneo, A., \& Wunsam, S. (2004). A test of the integrity of metal records in sediment cores based on the documented history of metal contamination in Lac Dufault (Quebec, Canada). Journal of Paleolimnology, 32, 149-162.

Dauvalter, V. (1994). Heavy metals in lake sediments of the Kola Peninsula, Russia. The Science of the Total Environment, 158, 51-61.

Dixit, S. S., Dixit, A. S., \& Smol, J. P. (2002). Diatom and chrysophyte transfer functions and inferences of postindustrial acidification and recent recovery trends in Killarney lakes (Ontario, Canada). Journal of Paleolimnology, 27, 79-96.

Eggimann, D. W., Manheim, F. T., \& Betzer, P. R. (1980). Dissolution and analysis of amorphous silica in marine sediments. Journal of Sedimentary Petrology, 50(1), 215225.

Engstrom, D. R., \& Wright, H. E. (1984). Chemical stratigraphy of lake sediments as a record of environmental change. In E. Y. Haworth \& J. W. G. Lund (Eds.), Lake sediments and environmental history (pp. 11-68). Leicester: Leicester University Press.

Gäbler, H.-E., \& Suckow, A. (2003). Chronology of anthropogenic heavy-metal fluxes and $\mathrm{Pb}$ isotope ratios derived from radiometrically dated lake sediments in northern Germany. Water, Air, and Soil Pollution, 144, 243-262.

Gallon, C., Tessier, A., Gobeil, C., \& Beaudin, L. (2005). Sources and chronology of atmospheric lead deposition to a Canadian Shield lake: Inferences from $\mathrm{Pb}$ isotopes and PAH profiles. Geochimica et Cosmochimica Acta, 69(13), 3199-3210.

Glew, J. R., Smol, J. P., \& Last, W. M. (2001). Sediment core collection and extrusion. In W. M. Last \& J. P. Smol (Eds.), Tracking environmental change using lake sediments. Volume 1: Basin analysis, coring, and chronological techniques (pp. 73-105). Dordrecht: Kluwer.

Goslar, T., Ralska-Jasiewiczowa, M., Van Geel, B., Łącka, B., Szeroczyńska, K., Chróst, L., et al. (1999). Anthropogenic changes in the sediment composition of Lake Gościąż (central Poland), during last 330 yrs. Journal of Paleolimnology, 22, 171-185.

Håkanson, L., \& Jansson, M. (2002). Principles of lake sedimentology. Caldwell: Blackburn.

Heiri, O., Lotter, A. F., \& Lemcke, G. (2001). Loss on ignition as a method for estimating organic and carbonate content in sediments: Reproducibility and comparability of results. Journal of Paleolimnology, 25, 101-110.

Johansson, K., Andersson, A., \& Andersson, T. (1995). Regional accumulation pattern of heavy metals in lake sediments and forest soils in Sweden. The Science of the Total Environment, 160(161), 373-380.
Kashulin, N. A., Ratkin, N. E., Dauvalter, V. A., \& Lukin, A. A. (2001). Impact of airborne pollution on the drainage area of subarctic lakes and fish. Chemosphere, 42, 51-59.

Klavinš, M., Briede, A., Klavina, I., \& Rodinov, V. (1995). Metals in sediments of lakes in Latvia. Environment International, 21(4), 451-458.

Kobber, B., Wessels, M., Bollhöfer, A., \& Mangini, A. (1999). $\mathrm{Pb}$ isotopes in sediments of Lake Constance, Central Europe constrain the heavy metal pathways and the pollution history of the catchment, the lake and the regional atmosphere. Geochimica et Cosmochimica Acta, 63(9), 1293-1303.

Lepš, J., \& Šmilauer, P. (2003). Multivariate analysis of ecological data using CANOCO. Cambridge: Cambridge University Press.

Lorenc, H. (Ed.). (2005). Climatic atlas of Poland (In Polish: Atlas klimatu Polski). IMGW: Warszawa.

Lucotte, M., Mijcci, A., Hillaire-Marcel, C., Hchet, P., \& Grondin, A. (1995). Anthropogenic mercury enrichment in remote lakes of northern Quebec (Canada). Water, Air, and Soil Pollution, 80, 467-476.

Marszelewski, W. (2005). Changes of the abiotic conditions in the lakes of north-east Poland (In Polish: Zmiany warunków abiotycznych $w$ jeziorach Polski Pótnocno-Wschodniej). Toruń: Wydawnictwo UMK.

Moiseenko, T. I., Kudryavtseva, L. P., Rodyushkin, I. V., Dauvalter, V. A., Lukin, A. A., \& Kashulin, N. A. (1995). Airborne contamination by heavy metals and aluminum in the freshwater ecosystems of the Kola Subarctic region (Russia). The Science of the Total Environment, 160(161), 715-727.

Nriagu, J. O. (1996). A history of global metal pollution. Science, 272, 223-224.

Olendrzyński, K., Dębski, B., Skośkiewicz, J., Kargulewicz, I., Cieślińska, J., Olecka, A., et al. (2007). Emission inventory of $\mathrm{SO}_{2}, \mathrm{NO}_{2}, \mathrm{NH}_{3}, \mathrm{CO}, \mathrm{PM}, \mathrm{HMs}, \mathrm{NMVOCs} i$ POPs in Poland in 2005 (In Polish: Inwentaryzacja emisji do powietrza $\mathrm{SO}_{2}, \mathrm{NO}_{2}, \mathrm{NH}_{3}, \mathrm{CO}$, pyłów, metali ciężkich, NMLZO i TZO w Polsce za rok 2005). Warszawa: Instytut Ochrony Środowiska.

Pempkowiak, J. (1991). Enrichment factors of heavy metals in the southern Baltic sediments dated with ${ }^{210} \mathrm{~Pb}$ and ${ }^{137} \mathrm{Cs}$. Environment International, 17, 421-428.

Quinlan, R., \& Smol, J. P. (2002). Regional assessment of longterm hypolimnetic oxygen changes in Ontario (Canada) shield lakes using subfossil chironomids. Journal of Paleolimnology, 27, 249-260.

Renberg, I., Bränvall, M. L., Bindler, R., \& Emteryd, O. (2000). Atmospheric lead pollution history during four millennia (2000 BC to 2000 AD) in Sweden. Ambio, 29, $150-156$.

Rognerud, S., \& Fjeld, E. (2001). Trace element contamination of Norwegian lake sediments. Ambio, 30(1), 11-19.

Schottler, S. P., \& Engstrom, D. R. (2006). A chronological assessment of Lake Okeechobee (Florida) sediments using multiple dating markers. Journal of Paleolimnology, 36, 19-36.

Shotbolt, L., Hutchinson, S. M., \& Thomas, A. D. (2006). Sediment stratigraphy and heavy metal fluxes to reservoirs in the southern Pennine uplands, UK. Journal of Paleolimnology, 35, 305-322. 
Smol, J. P. (2008). Pollution of lakes and rivers: A paleoenvironmental perspective. Oxford: Blackwell.

Stumm, W., \& Baccini, P. (1978). Man-made chemical perturbation of lakes. In A. Lerman (Ed.), Lakes. Chemistry, geology \& physics (pp. 91-126). New York: Springer.

Turekian, K. K., \& Wedepohl, K. H. (1961). Distribution of the elements in some major units of the Earth's crust. Bulletin of the Geological Society of America, 72, 175-184.

Tylmann, W. (2004). Estimating recent sedimentation rates using ${ }^{210} \mathrm{~Pb}$ on the example of morphologically complex lake (Upper Lake Raduńskie, N Poland). Geochronometria, 23, 21-26.

Tylmann, W. (2005). Lithological and geochemical record of anthropogenic changes in recent sediments of a small and shallow lake (Lake Pusty Staw, northern Poland). Journal of Paleolimnology, 33, 313-325.

Tylmann, W. (2007). Coring and subsampling of undisturbed recent lake sediments with high water content-Remarks about methodology and equipment (In Polish: Pobór i opróbowanie powierzchniowych, silnie uwodnionych osadów jeziornych o nienaruszonej strukturze - uwagi metodyczne i stosowany sprzęt). Przegląd Geologiczny, 55(2), 151-156.

Tylmann, W., Blanke, L., Ohlendorf, C., \& Zolitschka, B. (2007). Multiple-dating of varved sediments from Lake Łazduny, North-Eastern Poland: Preliminary results. Abstracts \& Programme, 9th International Conference "Methods of Absolute Chronology" (p. 99). Gliwice: Silesian University of Technology.

Weiss, D., Shotyk, W., \& Kempf, O. (1999). Archives of atmospheric lead pollution. Die Naturwissenschaften, 86, 262-275.

Żurek, S. (1986). Accumulation rate of peats and gyttjas in the profile of peatlands and lakes of Poland-As based on the radiocarbon dating (In Polish: Szybkość akumulacji torfu i gytii w profilach torfowisk i jezior Polskina podstawie danych ${ }^{14} \mathrm{C}$ ). Przeglad Geograficzny, LVIII (3), 459-477. 